\title{
Review
}

Pathobiology

\section{Sepsis: Going to the Heart of the Matter}

\author{
Mara R.N. Celes Cibele M. Prado Marcos A. Rossi \\ Laboratory of Cellular and Molecular Cardiology, Department of Pathology, Faculty of Medicine of Ribeirão Preto, \\ University of São Paulo, Ribeirão Preto, Brazil
}

\section{Key Words}

Cadherin - Calpain · Dantrolene $\cdot$ Dystrophin-glycoprotein complex $\cdot$ Heart $\cdot$ Intercalated disc $\cdot$ Myocardial dysfunction · Sepsis · Septic cardiomyopathy · Verapamil

\begin{abstract}
Although myocardial depression is the predominant cause of death in severe sepsis/septic shock, it remains disputed whether the functional changes are a consequence of structural alterations. If we look at myocardial dysfunction from the perspective of a critically ill patient, there are a few questions to be asked: What causes myocardial dysfunction? What is the pathophysiology of cardiac dysfunction and death? Is there something that could be done to prevent the outcome? Each of these questions is interrelated and the answers will be more easily addressed if we continue to understand the basic mechanisms that are implicated. The principal mechanisms proposed for the pathogenesis of myocardial dysfunction support a prominent role for functional rather than anatomical abnormalities. However, attempts to reduce the high mortality in septic patients by manipulating the functional alterations have provided limited success. In recent years, the concept of septic cardiomyopathy has evolved, which implies alterations in the myocardial phenotype. This review includes an overview on the activation of
\end{abstract}

the immune system and therapeutic approaches in sepsis, myocardial structural changes in the human septic heart, experimental models of sepsis, and cellular, molecular and functional myocardial changes seen in a variety of experimental sepsis models. The abnormal parameters discussed may emerge as therapeutic targets, for which modulation might provide beneficial effects on cardiovascular outcome and mortality in sepsis in the future.

Copyright $\odot 2012$ S. Karger AG, Base

\section{Introduction}

Sepsis is considered the most important cause of morbidity and mortality in intensive care units and can be defined as 'the systemic inflammatory response syndrome (SIRS) that occurs during infection' usually aggravated by multiple physiological and immunological abnormalities according to a consensus conference $[1,2]$. In other words, sepsis is a complex disease process wherein the body's response to a pathogen is amplified far beyond the initial site of infection. The development of hemodynamic changes with tissue hypoperfusion results in the multiple organ dysfunction syndrome characterizing severe sepsis. Septic shock is defined as hypotension refractory to fluid resuscitation. The heart is an important tar-

\section{KARGER}

Fax +4161306 1234

E-Mail karger@karger.ch

www.karger.com
(C) 2012 S. Karger AG, Basel

$1015-2008 / 13 / 0802-0070 \$ 38.00 / 0$

Accessible online at:

www.karger.com/pat
Prof. Marcos Rossi

Laboratory of Cellular and Molecular Cardiology, Department of Pathology

Faculty of Medicine of Ribeirão Preto, University of São Paulo

Ribeirão Preto, SP 14049-900 (Brazil)

Tel. +55 163602 3130,E-Mail marossi@fmrp.usp.br 
get organ in severe sepsis/septic shock. Recent definitions recognize the importance of myocardial depression in sepsis, including a low cardiac index or echocardiographic evidence of cardiac dysfunction [2]. Approximately $60 \%$ of patients admitted to intensive care units present a clinical picture of cardiac dysfunction that has been recognized as a serious manifestation in severe sepsis, with mortality ranging from 70 to $90 \%$, in contrast with $20 \%$ of mortality in septic patients without cardiovascular involvement $[3,4]$.

The main proposed mechanisms underlying the pathophysiology of myocardial dysfunction in sepsis support a prominent role for functional rather than anatomical abnormalities [5]: (a) microvascular dysfunction with reduced microcirculatory flow and increased heterogeneity as well as impaired myocardial oxygen extraction [6]; (b) autonomic deregulation of $\beta$-adrenergic receptors and postreceptor signaling pathway depression [7]; (c) metabolic disorders mediated through $\beta_{1}$-adrenergic receptors [8] and inducible nitric oxide synthase (NOS)-dependent action [9]; (d) mitochondrial dysfunction as a consequence of mitochondrial outer membrane destabilization with increased release of cytochrome c $[10,11]$; (e) increased release of pro-inflammatory cytokines such as tumor necrosis factor (TNF)- $\alpha$, interleukin (IL)-1 and IL-6 [12]; (f) cardiac-depressant action of lysozyme $c$ originated mainly from disintegrating neutrophils and monocytes [13]; (g) NO-mediated depression due to activation of constitutive, endothelial and neuronal NOS (nNOS), in early septic myocardial depression and inducible NOS in late sepsis [14]; (h) peroxynitrite, a by-product of $\mathrm{NO}$ overproduction, as a modulator of long-term myocardial depression [15]; (i) apoptotic myocardial cell death via activation of extrinsic (TNF- $\alpha$-related apoptosis resulting in the activation of caspase-8) and intrinsic (mitochondrial) pathways [16], and ( $\mathrm{j}$ ) reduced cytosolic calcium levels due to autonomic-related L-type calcium channel suppression in myocytes during the hyperdynamic phase of sepsis [17] and reduced release of calcium from sarcoplasmic reticulum via decreased ryanodine receptor type 2 density during the hypodynamic septic shock [18].

Attempts to reduce high mortality rates of patients with sepsis, severe sepsis and septic shock by manipulating these functional alterations have provided limited success [19]. Conceptualizing cardiac depression in sepsis as simply the result of biochemical/functional changes, however, oversimplifies the issue. Although in recent years the concept of septic cardiomyopathy has evolved [20-24], which implies alterations in the myocardial phe- notype in response to a variety of agents acting on heart cells, the importance of myocardial structural changes in sepsis has been overlooked. This septic cardiomyopathy, unlike the classic cardiomyopathy, which is not reversible and associated with high left ventricular (LV) filling pressures, involves both the left and right ventricles and is potentially reversible presenting depressed LV systolic function associated with normal or low ventricular filling pressures [24]. The normal or low LV pressures are related to right ventricular dysfunction directly linked to acute pulmonary hypertension associated with acute lung damage and/or an increase in LV compliance. Nevertheless, although in septic patients death usually results from progressive multiple organ failure rather than overwhelming primary infection and hyperinflammation, it has been rejected a long time that cardiac involvement forms part of a septic multiple organ syndrome. This review includes an overview on the activation of the immune system and therapeutic approaches in sepsis, myocardial structural changes in the human septic heart, experimental models of sepsis, and cellular, molecular and functional myocardial changes seen in a variety of experimental sepsis models.

\section{Activation of the Immune System in Sepsis}

Sepsis is characterized by initial overactivation of the innate immune system, which leads to the production of great amounts of pro-inflammatory mediators. During this so-called hyperinflammatory phase, major inflammatory cytokines, such as TNF- $\alpha$, IL- $1 \beta$ and IL- 6 , and chemokines, such as monocyte chemoattractant proteins (MCP-1), are increased following cecal ligation and puncture (CLP) [25].

Invasive microorganisms release pathogen-associated molecule patterns (PAMPs), such as lipopolysaccharide (LPS), lipoteichoic acid, flagellin and DNA in bacteria, mannan in fungi, and single- or double-stranded RNA in viruses, at the same time as infection-damaged tissue releases endogenous molecules known as alarmins. In conjunction, PAMPs and alarmins constitute the larger family of damage-associated molecular patterns (DAMPs) [26]. Pattern recognition receptors, expressed in immune effector cells, known as Toll-like receptors (TLRs), mediate the recognition of DAMPS, PAMPs and alarmins, which are thought to trigger the inflammation response. In favorable conditions, the infection-induced response is controlled through intracellular signaling, production of antagonists that neutralize pro-inflammatory cyto- 
kines, production of anti-inflammatory cytokines (e.g. IL-10) and specific silencing of pro-inflammatory genes. In sepsis, for as yet poorly understood reasons, normally beneficial responses fighting infection are turned into a systemic inflammatory response dysregulation (SIRS) due to markedly imbalanced cytokine responses usually referred as cytokine storm.

Ten TLRs have been identified in the human genome [27]. The complex formed by TLR 4 with the myeloid cell antigen CD14 and the myeloid differentiation factor-2 (MD-2) and LPS, the most powerful of all the PAMPs, (TLR-4-MD-2-CD14-LPS) illustrates the remarkable versatility of the ligand mechanisms employed by the TLR family, which is essential for defense against diverse microbial infections [28]. The complex TLR4-MD-2CD14-LPS activates intracellular signal-transduction pathways that lead to the activation of cytosolic nuclear factor $-\kappa \mathrm{B}(\mathrm{NF}-\kappa \mathrm{B})$ that moves to the nucleus, binds to transcription initiation sites and increases the transcription of inflammatory mediators [29]. Among them, lipid mediators such as prostaglandins, leukotrienes and platelet-activating factor, proinflammatory cytokines such as TNF- $\alpha$ and IL-1 $\beta$, chemokines such as macrophage inflammatory proteins (MIP- $1 \alpha$ and MIP-2) and a keratinocyte-derived chemokine (IL-8 homologue in mice), play a major role in orchestrating the inflammatory process [25]. It is also known that cytokines further enhance the microbicidal activities of phagocytes, contributing to the recruitment of leukocytes towards the site of infection. The recruited leukocytes are crucial to protection and eradication of invading microorganisms. However, the excessive production of antimicrobial products and inflammatory mediators leads to the production of reactive oxygen and nitrogen species, superoxide anion $\left(\mathrm{O}_{2}^{-}\right)$and $\mathrm{NO}$, respectively, favoring adjacent tissue damage and amplification of the inflammatory reaction [30, 31]. Besides, IL-17A, the first described member of the IL-17 family, is suggested to be an important contributor to the amplification of the inflammatory reaction with adverse effects on survival in experimental sepsis [32]. Also, the initial phase of sepsis is characterized by the release of catecholamines due to activation of the sympathetic nervous system stimulating adrenoreceptors $\alpha$ and $\beta$ expressed on immune cells. Ligation to adrenoreceptor $\alpha$ is associated with predominantly immunostimulating effects through increased production of proinflammatory cytokines (mainly TNF and IL-1) while ligation to adrenoreceptor $\beta$ usually has immunosuppressive consequences (inhibition of TNF and IL-1 and induction of IL-10) [33].
The initial hyperinflammatory cytokine storm is followed by the production of contra-inflammatory proteins, such as IL-10, IL-1 receptor antagonist, transforming growth factor $\beta$, soluble receptors of TNF- $\alpha$ (sTNFRI and sTNFRII) and IL-1 (sIL-1R) and glucocorticoids (GC), which lessen the hyperinflammatory response causing a protracted period of immune suppression or a hypoinflammatory phase. This septic immune dysfunction called compensatory anti-inflammatory response syndrome occurs when the patients or the experimental animals survive the hyperinflammatory phase, which makes them less responsive to neoantigens or recall antigens and more prone to develop infections (nosocomial infections in the case of septic patients) $[25,34]$.

\section{Therapeutic Approaches in Sepsis}

Current management of sepsis is largely supportive and consists of the administration of broad-spectrum antibiotics aiming at the infectious focus and hemodynamic support with fluids, vasopressors and inotropes.

Based on the premise that sepsis is a dysregulation of the immune system, novel therapeutic drugs target particularly the suppression of the inflammatory response by aiming at cytokines, coagulation factors and the complement system. However, the translation of mechanisms of sepsis and proposed therapeutic strategies focused on the inflammatory response and derived from animal studies have failed, very likely, at least in part, due to the fact that the experimental models of sepsis do not entirely mimic human sepsis $[35,36]$. For instance, employing monoclonal antibody therapy with anti-TNF in experimental models of endotoxemia [37] and bacteremia [38] demonstrated a survival benefit whereas clinical trials in septic patients failed to demonstrate any outcome benefit with this treatment $[39,40]$. Similarly, the administration of an IL-1 receptor antagonist to modulate the excessive concentration of this receptor during experimental sepsis provided some survival benefit [41]; however, clinical trials with this same therapeutic intervention have not resulted in improvement of the survival rate in patients with severe sepsis [42]. Also, multiple experiments in different models of endotoxemia demonstrated beneficial effects of systemic corticosteroid administration [43, 44]. In contrast, randomized clinical trials using corticosteroid treatment did not improve the outcome of septic patients $[45,46]$. As TLR4 plays a central role in the sensing of LPS from Gram-negative bacteria and, consequently, in the pathogenesis of Gram-negative sepsis, TLR4 has 
become an attractive target for anti-sepsis therapies. Anti-TLR4 antibody administration, either therapeutically or prophylactically, demonstrated to reduce the production of cytokines and to markedly improve survival in mice submitted to endotoxic shock and Escherichia coli sepsis [47]. Moreover, TLR4 knockout mice (TLR4 ${ }^{-/}$) were completely resistant to $E$. coli-induced septic shock while TLR $2^{-/}$and wild-type mice developed a fulminant sepsis. In contrast, an anti-TLR4 compound, eritoran tetrasodium, failed to demonstrate any improvement in the mortality of severe sepsis patients in comparison with a placebo in a third-phase worldwide randomized trial [48].

As the characteristic intense inflammatory response in sepsis is linked to coagulation activation and fibrinolysis inhibition, activated protein $\mathrm{C}$ has been administered to patients with severe sepsis due to its well-documented inhibitor effects on coagulation and fibrinolytic activity beside its anti-inflammatory, anti-apoptotic and anti-histone activities [49]. Based on a first clinical trial, PROWESS, which demonstrated a modest $13 \%$ improvement in survival, Xigris, a recombinant activated protein $\mathrm{C}$ produced by Eli Lilly, was approved for clinical use, except in patients at risk to bleed, in infants and in immunosuppressed patients, especially those with thrombocytopenia or neutropenia. However, following a worldwide trial failure, PROWESS Shock, this drug was withdrawn from the market [50].

Statins have also been proposed for the treatment of sepsis due to its beneficial anti-inflammatory, immunomodulatory and direct antimicrobial effects. However, the controversial results from experimental and clinical studies do not give a definitive answer for the use of statins for treating bloodstream infection and sepsis, stressing the need for a large randomized controlled trial on statin treatment in patients with severe sepsis [51].

Early sepsis is also characterized by massive release of catecholamines from the autonomic nervous system, gut, lymphocytes, macrophages and neutrophils causing sympathetic activation and consequent persistent stimulation of $\alpha$ - and $\beta$-adrenergic receptors [52]. This response causes a hypermetabolic state and an intense inflammatory response. Recent studies have demonstrated that a selective $\beta_{1}$-blocker, esmolol, improves the outcome of CLP-induced sepsis in rats through modulation of mucosal integrity and local inflammatory responses [53]. Previously, it was demonstrated that esmolol infused in septic rats attenuated the development of myocardial dysfunction in an ex vivo experimental study [54]. In contrast, the use of propanolol, a non-selective $\beta$-adren- ergic blocker, demonstrated a negative impact on mice submitted to CLP-induced sepsis [55] probably due to inhibition of $\beta_{2}$-adrenergic receptors that protect the myocardium [56]. Similarly, the administration of a specific $\alpha_{2 \mathrm{~A}}$-adrenergic receptor antagonist given $5 \mathrm{~h}$ after CLP in rats inhibited the local inflammatory response associated with attenuated local tissue injury evaluated $20 \mathrm{~h}$ after surgery and significantly improved survival evaluated 10 days after CLP [57].

\section{Cardiac Structural Changes in Human Severe Sepsis}

Although myocardial depression is the predominant cause of death in severe sepsis/septic shock, it remains disputed whether this functional alteration is a consequence of structural changes. Elevated levels of troponins $\mathrm{T}$ and I were previously reported in critically ill patients not correlated with clinically recognized myocardial injury [58]. However, elevated levels of cardiac troponins indicate cardiac injury but do not define the cause of injury. Possible mechanisms proposed for the high troponin levels in sepsis include diffuse necrosis, proteolysis of cardiac troponins or troponin leakage out of the cell after reversible membrane disruption. A few works have been dealing with the cellular mechanisms directly dependent on sepsis/septic injury to explain the occurrence of myocardial structural changes in humans. At first, myocardial changes which were not clearly defined were reported after the analysis of 10 of patients in whom the cause of death was related to infectious processes [59]. After a long time period, a retrospective study evaluated 71 autopsy cases of septic patients classified based on morphologic criteria, which included inflammatory reactions in at least two organs, acute splenitis, bacterial acute pyelonephritis, fibrin/thrombin in the lungs, liver and glomeruli, and sequestered neutrophils in pulmonary capillaries [60]. The authors described a typical acute infectious myocarditis in 19 cases, which was characterized by interstitial neutrophil infiltration, sometimes with the formation of abscesses, bacterial colonization in 8 cases and foci of myocardial necrosis in 5 cases. Seventy-one age- and sex-matched autopsy cases in which the cause of death was not related to infection were used as controls. Clearly, the authors described typical cases of acute bacterial myocarditis; in spite of this, they proposed that blood-borne mediators would be the cause of myocardial damage and responsible for myocardial depression in human sepsis. Cellular and molecular mechanisms demonstrating myocardial structural changes in long-term hu- 


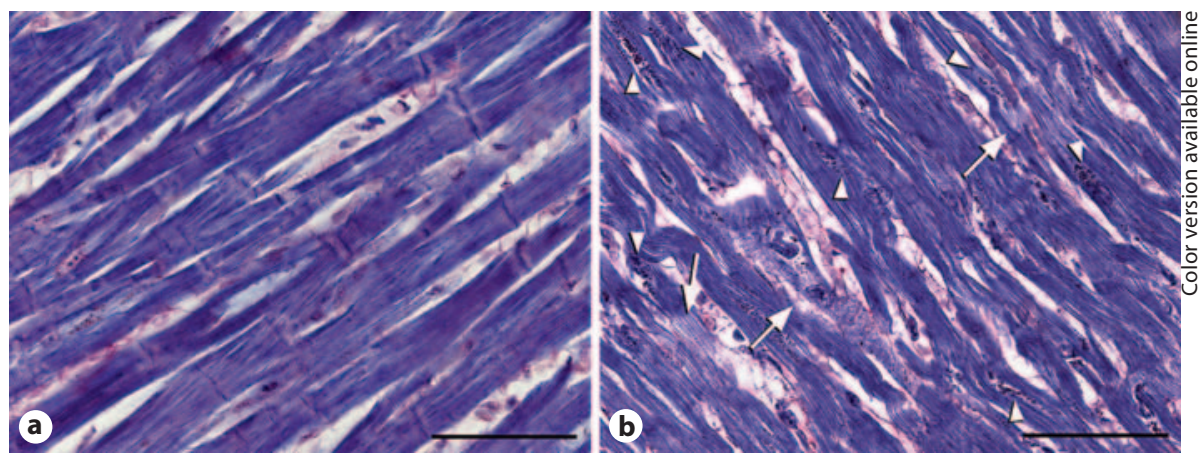

Fig. 1. a Representative image of a longitudinal section of a human control myocardium showing regularly stained cardiomyocytes with distinct cross-striations. b Representative image of a longitudinal section of human septic myocardium showing loss of distinct cross-striations and lysis of myofilaments (white arrows). The white arrowheads indicate black granules around the nuclei or the central portion of cardiomyocytes corresponding to a markedly increased number of lipofuscin granule formation as indicator of oxidative stress and disruption of plasma membrane phospholipids by lipid peroxidation and protein nitration. An interstitial mononuclear infiltrate can be seen in septic hearts, in contrast to control hearts. Paraffin-embedded material, phosphotungstic acid-hematoxylin stain. Scale bars $=50 \mu \mathrm{m}$. man sepsis have been described recently [26]. Human hearts obtained at autopsy were examined: cases of severe sepsis/septic shock with severe acute lung injury were studied (mean age of 59 years, with a prolonged mean time of hospitalization in the intensive care unit of 24.3 days); cases with severe acute lung injury as a consequence of SIRS due to severe acute necrotizing pancreatitis served as SIRS controls (mean age of 52 years), and cases of accidental death without thoracic injury served as normal controls. The main findings in severe sepsis/ septic shock cases included myocardial changes classified within the group of specific cardiomyopathies and named inflammatory cardiomyopathy [61]. A very high number of macrophages, most of them with morphological features of activation, associated with high diffuse expression of TNF- $\alpha$ localized to cardiomyocytes, macrophages, smooth muscle cells and endothelial cells were observed in septic hearts in contrast with the findings in both SIRS and normal controls, except for 2 cases of acute pancreatitis expressing TNF- $\alpha$ in the few interstitial macrophages. Macrophages are known to be able to cause contractile impairment in experimentally induced endotoxemia in mice through TNF- $\alpha$ via both receptors TNFR-I and TNFR-II [62]. In addition, TNF- $\alpha$ by itself is a powerful cytokine that can cause cardiac dysfunction and cardiomyocyte death through disruption of calcium handling [63]. Moreover, intracytoplasmic lipid accumulation in cardiac myofibers of septic hearts was observed, very likely reflecting myocardial dysfunction. It is known that during heart failure the cardiac muscle changes from the normally preferred fuel of free fatty acids to glucose, which results in an imbalance between the uptake and consumption of fatty acids and consequent lipid accumulation in cardiomyocytes [64]. Also, increased expression of nitrotyrosine and inducible NOS were disclosed in cardiomyocytes and macrophages of septic hearts in contrast to controls. The increased production of nitrotyrosine, a biomarker of peroxynitrite formation, indicates increased production of $\mathrm{NO}$ and $\mathrm{O}_{2}^{-}$that interact to produce nitrotyrosine. These changes were associated with spread foci of actin/myosin disruption, thus suggesting that oxidative damage may play a key role in actin/myosin disruption in the hearts of septic patients (fig. 1).

\section{Experimental Models of Sepsis}

Over years, many research groups have been trying to establish animal models that present an appropriate similarity to human sepsis, such as challenge with endotoxin (LPS) or exotoxin (lipoteichoic acid) and intraperitoneal or intravenous administration of live organisms $[35,65]$. It is well known that during sepsis/septic shock, the entrance of bacteria or LPS into the circulation is small, raising the question whether these models really mimic the development of sepsis. Wichterman et al. [66] proposed the CLP model in 1980; since then, numerous animal species have been used for inducing sepsis by CLP, including rats, mice, sheep and dogs. This model of sepsis is considered, up to now, the most realistic condition, drawing a parallel between the experimental and the clinical situations [67]. This insult is a clinically relevant 
and acceptable model of acute peritonitis that has been used to study the systemic response to infection, closely resembling the clinical situation of bowel perforation and polymicrobial acute peritonitis. Additionally, in small animals, such as mice and rats, this model can be induced by a simple surgical procedure with no need to grow and quantify bacteria or prepare the inocula. Moreover, increasing the thickness of the needle used to puncture the ligated cecum, the magnitude of the septic challenge could be controlled. The CLP model has substantially contributed to our understanding of many pathophysiological and immunological features of sepsis and has been considered the gold standard model of sepsis. However, it does not reproduce the whole complexity of the clinical situation. Preclinical animal experiments may be too simplistic because the animals are usually young and have no comorbidity. In contrast, patients with sepsis are often older and have underlying comorbidity, both of which are strong predictors of sepsis susceptibility and outcome. Also, antibiotics and supportive care are not given in animal models. This may explain, at least in part, the reason why, despite a clear therapeutic rationale based on experimental evidence, anti-inflammatory therapies targeting innate or acquired immune responses have been largely unsuccessful in clinical trials of sepsis [68]. Another possible reason is that the mechanism of multiple organ failure in sepsis is not only a consequence of an imbalance between host immune response and pathogen virulence and load: it is well known that the cause of death of septic patients is multiple organ failure [69], but its pathogenesis is still incompletely understood [70]. This review deals with the intrinsic pathogenic mechanism of one of the most important manifestations of sepsis: the pathogenesis of myocardial dysfunction/septic cardiomyopathy.

\section{Cardiac Structural Changes in Experimental Sepsis}

Previous experimental studies have shown either an association between sepsis and cardiac morphological alterations (most of them not correlated with cardiac functional evaluation) or impairment of myocardial contractility in the absence of myocardial damage.

Experimental studies using a model of sepsis induced by intravenous infusion of live bacterial organisms reported structural myocardial injury characterized by interstitial and intracellular edema [71,72], focal mitochondrial swelling [71], subendocardial hemorrhage [72] and generalized glycogen depletion [71]. Intracellular edema, mitochondrial damage and cell necrosis $[73,74]$ have been reported in rats and sheep using the CLP model of sepsis. Moreover, using a canine model of sepsis induced by live bacterial injection into the peritoneal cavity, myocardial neutrophil infiltration, endothelial cell edema, microcirculatory fibrin deposition, focal myofibrillar dissolution and mitochondrial swelling with myelin figure formation were associated with a reduction in both ejection fraction and fractional shortening/cardiac dysfunctional changes [75]. On the other hand, isolated hearts perfused by support rabbits given endotoxin (1 $\mathrm{mg} / \mathrm{kg}$ of body weight i.v. over $30 \mathrm{~min}$ ) showed a significant reduction in cardiomyocyte contractility associated with cardiac structural abnormalities characterized by diffuse foci of cardiomyocytes presenting cytoplasmic and nuclear tumefaction and/or vacuolization, contraction band formation and cell necrosis [76]. The authors concluded that the myocardial changes were caused by blood-borne factors, including plasma and cellular elements. In contrast, using the CLP model for induction of polymicrobial sepsis in rats, depressed myocardial contractility was observed 24 and $48 \mathrm{~h}$ after septic injury [77] or normal myocardial contractility detected $20 \mathrm{~h}$ after the septic injury [78]; both observations did not correlate with myocardial structural alterations.

\section{Changes in the Contractile Apparatus of Cardiomyocytes in Severe Experimental Sepsis}

Striated cardiac and skeletal muscle cells are characterized by contraction and relaxation properties. Cardiac muscle is defined as involuntary contraction but skeletal muscle contracts voluntarily. Striated myofiber contains myofibrils formed by repeating units of sarcomeres, arranged in series, which are in turn composed of parallel filaments of two types: the thick filament is a polymer composed of myosin molecules while the thin filament has a two-threaded helical structure, the chief support of which is composed of polymerized globular actin monomers. In this scaffold, a series of regulatory proteins modulate the interaction between the thick and the thin filaments. The regulation of the contraction cycle of striated muscles is calcium dependent. Calcium is released from the sarcoplasmic reticulum regulating a cascade of events that include changes in protein-protein interaction and structural changes in proteins leading to muscle contraction. Moreover, the muscle contraction depends on the energy provided by the mitochondria. Mitochondria and sarcoplasmic reticulum acquire a specific position rela- 
Fig. 2. a Representative image of control myocardium of mice $24 \mathrm{~h}$ after sham operation. b Representative image of myocardium of mice $24 \mathrm{~h}$ after CLP surgery showing foci of myocytolysis and cardiomyocyte tumefaction (arrows). Inflammation is absent in the septic hearts, similarly to sham hearts. Plastic-embedded material, toluidine blue stain. Scale bars $=50 \mu \mathrm{m}$.
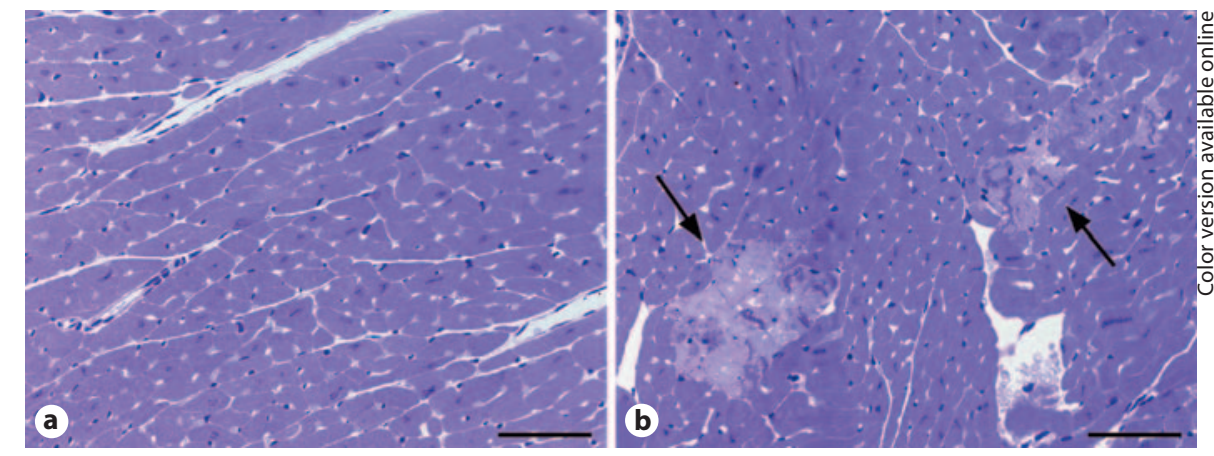

tive to myofibrils and each other, with the outer membrane of mitochondria being tethered to the adjacent sarcoplasmic reticulum.

Evidence from the pertinent literature indicates that sepsis causes decreased rates of ventricular relaxation and contraction of cardiomyocytes [79, 80]. Dysfunctional myocardial contractility in sepsis/septic shock has been ascribed to several mechanisms, such as myocardial ischemia, microvascular dysfunction, presence of cardiodepressive cytokines and increased production of $\mathrm{NO}$ with oxidative damage $[81,82]$. However, there are few experimental studies addressing the connection between alterations in the myocardial contractile apparatus and cardiac dysfunction in sepsis $[83,84]$. Recently, cardiac morphological changes were detected in the late periods of the septic process $(24 \mathrm{~h})$ in CLP mice and characterized by tumefaction of cardiomyocytes and diffuse foci of myocytolysis associated with focal disruption of the actin/myosin contractile apparatus (fig. 2). However, no inflammatory infiltrate in the myocardium could be seen at this same time point [85]. The measurement of individual diameters of cardiomyocytes demonstrated the heterogeneity between septic and control hearts. This study showed that $12 \mathrm{~h}$ after sepsis induction, cardiomyocytes from septic mice presented a $17 \%$ increase in the mean minor diameter in comparison with that of controls; $24 \mathrm{~h}$ after CLP, the mean minor diameter of cardiomyocytes from septic mice was $31 \%$ higher compared to that of the sham myocardium, reflecting intracellular edema. Cellular tumefaction caused by accumulation of intracellular fluids directly reflects increased plasma membrane permeability of cardiomyocytes [77, 86, 87]. Cardiac muscle protein expression, such as actin and myosin expression, differed in septic and healthy control animals. Immunofluorescent labeling of actin and myosin in control healthy hearts appeared as cross-striations in longitudinal sections due to the stacks of myofibrils com- posed of overlapping zones of thin filaments: actin - corresponding to I-bands of the sarcomeres and thick filaments - and myosin - corresponding to A-bands of the sarcomeres. In contrast, in septic hearts the localization of actin and myosin was focally disrupted, reflecting disruption of the actin/myosin filaments and of the sarcomeric arrangement; also, spread foci of myosin and actin filaments forming amorphous masses due to collapse of myofilaments could be found. Ultrastructurally, in the normal myocardium, the actin and myosin filaments, held in place by accessory proteins, form myofibril bands in a regular and parallel organization, which alternate with rows of mitochondria, sarcoplasmic reticulum and glycogen in the intermyofibrillar space. The ultrastructure of the septic myocardium showed striking degenerative changes defined by fragmentation, disorientation and dissolution of myofibrils, intermyofibrillar edema, hypercontracted myofibrils with the formation of anomalous contraction bands, mitochondrial changes characterized by enlargement, swelling, decreased matrix density and ruptured cristae, and, rarely, sarcolemmal rupture. The dissolution of actin/myosin filaments was in consonance with markedly reduced amounts of actin and myosin, as detected by immunoblotting, in septic hearts compared with healthy control hearts.

The hallmark of septic shock can be ascribed to a dysfunctional microcirculation that generates regional flow disturbances and abnormal tissue oxygenation, causing relative ischemia in many organs, including the heart $[86$, 88]. Moreover, the focal nature of the injury suggests that the microcirculation could be involved, i.e. the primary site of the disease could be at a level capable of inducing focal myocytolysis in discrete groups of cells. Increased permeability of the sarcolemma is considered a prominent characteristic of ischemic myocardial injury $[89,90]$ and could be the initiating event leading to cardiomyocyte damage and progression to cardiac dysfunction. The in- 
jury of the plasma membrane induces osmotic imbalance with the influx of ions and fluid associated with loss of proteins, enzymes, coenzymes and nucleic acids to the extracellular environment [87]. The detection of intracellular albumin to evaluate plasma membrane permeability demonstrated early evidence of sarcolemmal damage in septic hearts [85]. In healthy hearts, albumin was localized in the interstitial space as a delicate network and in the vascular lumina. In contrast, during experimental sepsis induced by CLP, albumin staining was markedly increased in the interstitial space and blocks of cardiomyocytes showed intracytoplasmic albumin consistent with increased sarcolemmal permeability instead of plasma membrane rupture. The implication of free radicals in the genesis of increased permeability of the plasma membrane of cardiomyocytes was demonstrated by its significant attenuation when septic mice were given a superoxide scavenger (superoxide dismutase, SOD) immediately after CLP surgery. In addition, the demonstration of lipid peroxidation and protein nitration in septic hearts, indicating damage to lipids and proteins, pointed to their involvement in the development of phenotypic changes of the myocardium that may progress to cardiac depression.

\section{Dystrophin-Glycoprotein Complex Disruption Can Destabilize the Sarcolemma and Cause Myofilamentar Degeneration}

The cytoskeleton of the cardiomyocyte forms an important structural interface with the extracellular environment and the contractile apparatus that transmits mechanical force within and between cells $[91,92]$. It also contributes substantially to cell stability by anchoring subcellular structures, such as mitochondria, Golgi apparatus, nuclei and myofibrils. The action of the cytoskeleton as a stabilizing force and as a mechanical transducer depends on membrane-associated proteins, especially dystrophin, the major component of the dystrophin-glycoprotein complex (DGC) located below the sarcolemma, which binds to both intracellular actin and laminin in the basal lamina [93]. This protein complex contributes to the maintenance of cell shape, mechanical strength and cardiomyocyte transduction of contractile force, allowing the interaction between the contractile system and the extracellular matrix [94-96]. It is concentrated along the plasma membrane of cardiomyocytes in costamere structures that correspond to Z-lines or Z-discs, which delimit the sarcomeres, thus positioning dystrophin and associated glycoproteins to the transmission of contraction force between the underlying contractile apparatus of sarcomeres and the sarcolemma to the extracellular matrix (primarily basal lamina and reticular lamina) that withstand the high contractile forces [94, 96-98].

The great importance of DGC in the maintenance of sarcolemmal stability and integrity and as a mechanical link between the actin cytoskeleton and the extracellular matrix led to the evaluation of the hypothesis that reduction/loss of dystrophin and associated glycoproteins could be involved in degenerative changes in cardiomyocytes and contractile force transmission impairment in severe sepsis induced by CLP in mice [99]. The mean amounts of dystrophin and $\beta$-dystroglycan were markedly reduced in septic hearts (50 and $42 \%$, respectively) compared with sham-operated controls. However, the mean amounts of laminin- $\alpha_{2}$ (one of the main components of the basement membrane) were similar in both groups. Importantly, the anti-oxidant treatment of mice with SOD given via intraperitoneal treatment immediately after the septic injury significantly attenuated the dystrophin reduction/loss and almost completely abrogated increased sarcolemmal permeability, in parallel with a significant improvement in survival rates $24 \mathrm{~h}$ after surgery: 50\% without administration of SOD and $28 \%$ with SOD treatment.

The organization and interaction between dystrophin and associated glycoproteins is necessary to understand the cellular mechanisms involved in the mechanical dysfunction observed during cardiomyopathies $[94,95,100]$. Recent investigations demonstrated differences in the sensitivity of the membrane-related proteins to experimentally induced myocardial ischemia in dogs when dystrophin was more affected than the transmembrane proteins dystroglycan, sarcoglycan, sarcospan, dystrobrevin and syntrophin [89]. Likewise, it has been demonstrated that dystrophin was the most sensitive structure among the DGC proteins in the hearts of rats given isoproterenol, a well-known cause of ischemic myocardial injury [92]. The reduction or collapsed expression of $\gamma$-sarcoglycan, $\beta$-dystroglycan, $\beta_{1}$-integrin and laminin- $\alpha_{2}$ were considered epiphenomena; these structures played a secondary role during the development of myocytolysis.

The cardiac reduction or loss of dystrophin expression could be an event associated with myofilamentar degeneration and/or myocytolysis due to cardiomyocyte destabilization. The mutations that reduce dystrophin-binding activity result in muscular dystrophy. Defects in the connection of dystrophin and associated glycoproteins to the extracellular matrix underlie most of the pathologic process seen in Duchenne muscular dystrophy patients as well as $m d x$ mice, an animal model of dystrophin gene 
Fig. 3. Schematic diagrams representing changes in DGC components in septic hearts. a In normal myocardium, dystrophin links actin to the transmembrane proteins dystroglycan and sarcoglycan. Dystroglycan binds to the extracellular matrix through laminin. It is represented that integrin also links actin to laminin in the extracellular matrix. b In septic myocardium, reduction/loss of dystrophin, $\beta$ dystroglycan and sarcomeric actin could result in rupture of the mechanical linkage that attaches the actin-based subsarcolemmal cytoskeleton and the sarcolemma to the extracellular matrix that may impair contractile force transmission.

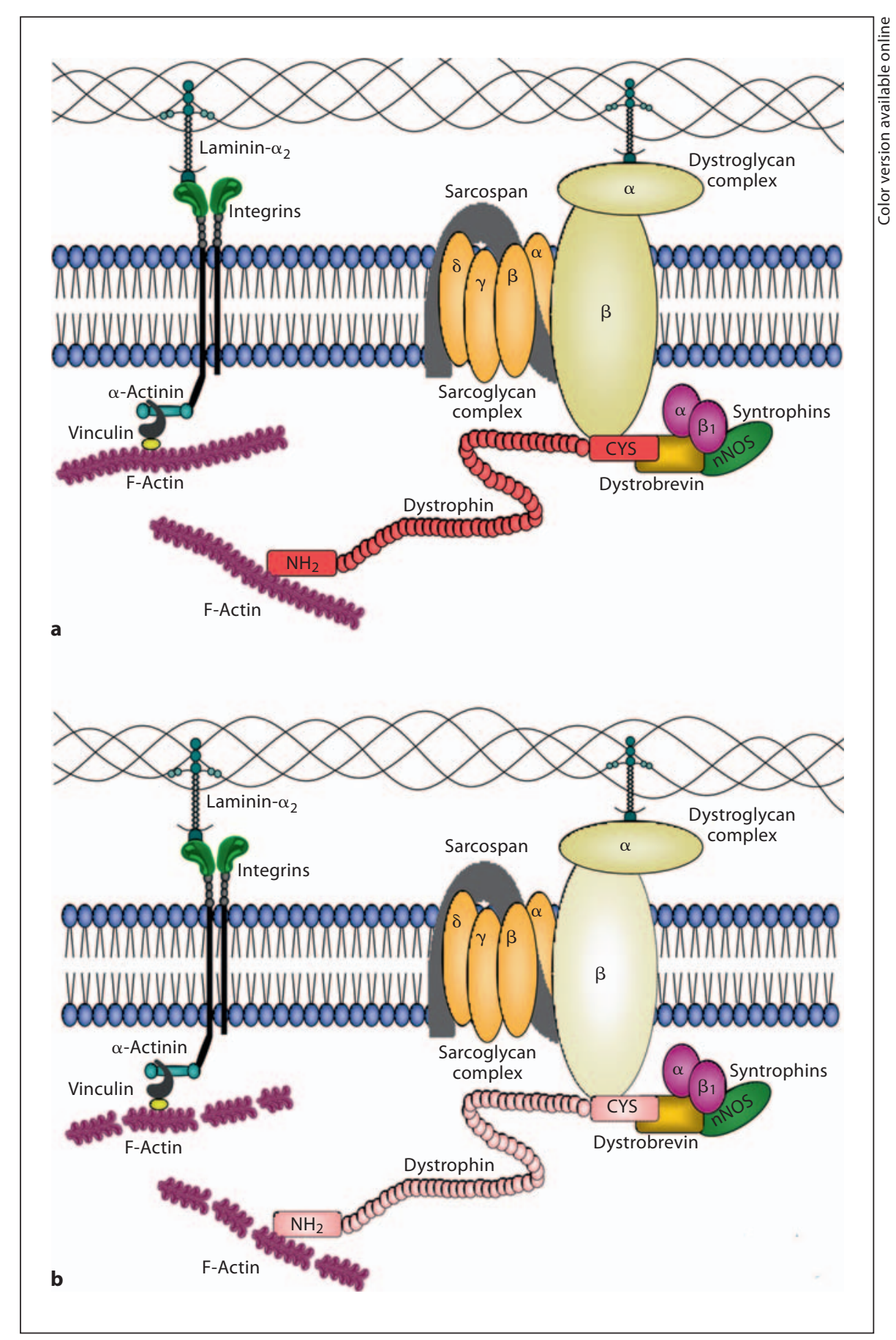

mutation [101], both being associated with the late development of cardiomyopathy. Moreover, loss of dystrophin has been proposed as a common route to the development of cardiomyopathies and contractile depression and progression to advanced heart failure [102]. Loss of dystrophin and associated glycoproteins reduces the mechani- cal integrity of the cardiac muscle eliciting a lower threshold to injuries with repeated stretched or eccentric contractions $[103,104]$. Also, as a result of dystrophin impairment, there is a significant reduction in the associated glycoproteins, mainly the transmembranous $\beta$-dystroglycan $[89,105]$. 
In summary, reduction/loss of dystrophin and $\beta$-dystroglycan could destabilize the sarcolemma causing myofilamentar degeneration and/or myocytolysis thus contributing to myocardial phenotypic changes and cardiac depression in sepsis/septic shock. This opinion is schematically illustrated in figure 3.

\section{Loss of the Structural Integrity of Intercalated Discs in Experimental Sepsis}

Intercalated discs (ID) are the membrane sites where individual cardiomyocytes are connected to each other. Three different types of cell-cell junctions are situated in the ID that ensure mechanical coupling between cells and enable propagation of electrical impulses throughout the heart: adherens junctions (fascia adherens), desmosomes (macula adherens) and gap junctions [106, 107]. Adherens junction is defined as a cell-cell junction composed of $\mathrm{N}$ cadherin that mediates cell-cell mechanical adhesion in connection to the actin cytoskeleton and its cytoplasmic partners, the catenins. It can appear as bands encircling each of the interacting cells (zonula adherens) or as spots of attachment to the extracellular matrix (adhesion plaques) [95]. The desmosome is a major cell adhesion junction that anchors cell membranes to the intermediate filament network, particularly in tissues undergoing constant physical stress, such as in the skin and the heart [108]. Gap junction allows intercellular communication between neighboring cardiomyocytes via electrical stimulation and ion transfer allowing the propagation of an action potential from cell to cell [109, 110]. Gap junction channels are constituted of dodecameric proteins consisting of two hexameric hemichannels, the connexons. Each connexon is composed of six connexin proteins that extend across cell membranes, with each of the neighboring cells providing one hemichannel. Gap junctional communications and the consequent integrative responses are directly dependent on correct connexin trafficking and their assembly into functional channels [110].

Taking into account that myocardial contractile function depends on ID for mechanical and electrical/chemical coupling of cardiomyocytes, the occurrence of ID changes in experimental CLP sepsis in mice was examined [111]. During sepsis, the ID was initially evaluated by analyzing the expression of connexin 43 and $\mathrm{N}$-cadherin. Connexin 43 and N-cadherin were clearly identified along the ID of normal cardiomyocytes whereas in left ventricles of septic hearts these proteins were strikingly reduced. Additionally, the protein levels were mark- edly decreased in the myocardium of septic animals in comparison with healthy normal hearts. These findings clearly demonstrated marked ID remodeling in septic hearts. Electron-microscopic studies disclosed dehiscence of both adherens and gap junctions in septic hearts in comparison with sham-control hearts. Cardiac-specific loss of cadherin responsible for ID dehiscence causing sudden cardiac death was recently demonstrated [112]. Besides, there is a significant reduction in connexin 43 in the gap junctions of $\mathrm{N}$-cadherin-knockout hearts in association with decreased ventricular conduction velocity [113]. In previous studies, adherens junction shaping was crucial to gap junction formation in cultured cardiomyocytes $[114,115]$. Moreover, ID contains great amounts of connexin 43 at gap junction plaques, reflecting their important function in electrically coupling cardiomyocytes. Previous studies have shown that loss of cardiac connexin 43 slows myocardial conduction velocity and induces unidirectional blockade causing an arrhyth mogenic substrate and sudden cardiac death in mice $[116,117]$.

In summary, the reduction in the proteins connexin 43 and $\mathrm{N}$-cadherin results in loss of the structural integrity of ID, which very likely changes the mechanical coupling and the electrochemical communication between neighboring cardiomyocytes and thus contributes to myocardial dysfunction in sepsis. This opinion is schematically illustrated in figure 4 .

\section{Evaluation of Cardiac Function during the Development of Experimental Sepsis}

Septic shock in humans is characterized by an early hyperdynamic phase (warm phase) with increased cardiac output, tachycardia and a reduction in systemic vascular resistance [118]. Soon after the onset of the illness, three fourths of the patients present a hypodynamic phase (cold shock) characterized by depression of LV ejection fraction, hypotension and ventricular dilatation [118-120]. The reduction in ejection fraction and ventricular dilatation can be solved in 10-14 days in surviving patients [3].

The functional consequences of the morphological findings in severe experimental sepsis induced by CLP in mice were evaluated by transthoracic wall echocardiography using a Vevo $2100{ }^{\circledR}$ high-resolution imaging system (Visual Sonics, Toronto, Ont., Canada) equipped with a $30-\mathrm{MHz}$ frequency transducer in septic and control mice $24 \mathrm{~h}$ after injury (fig. 5). Twenty-four hours after septic injury, mean ejection fraction, mean fractional 


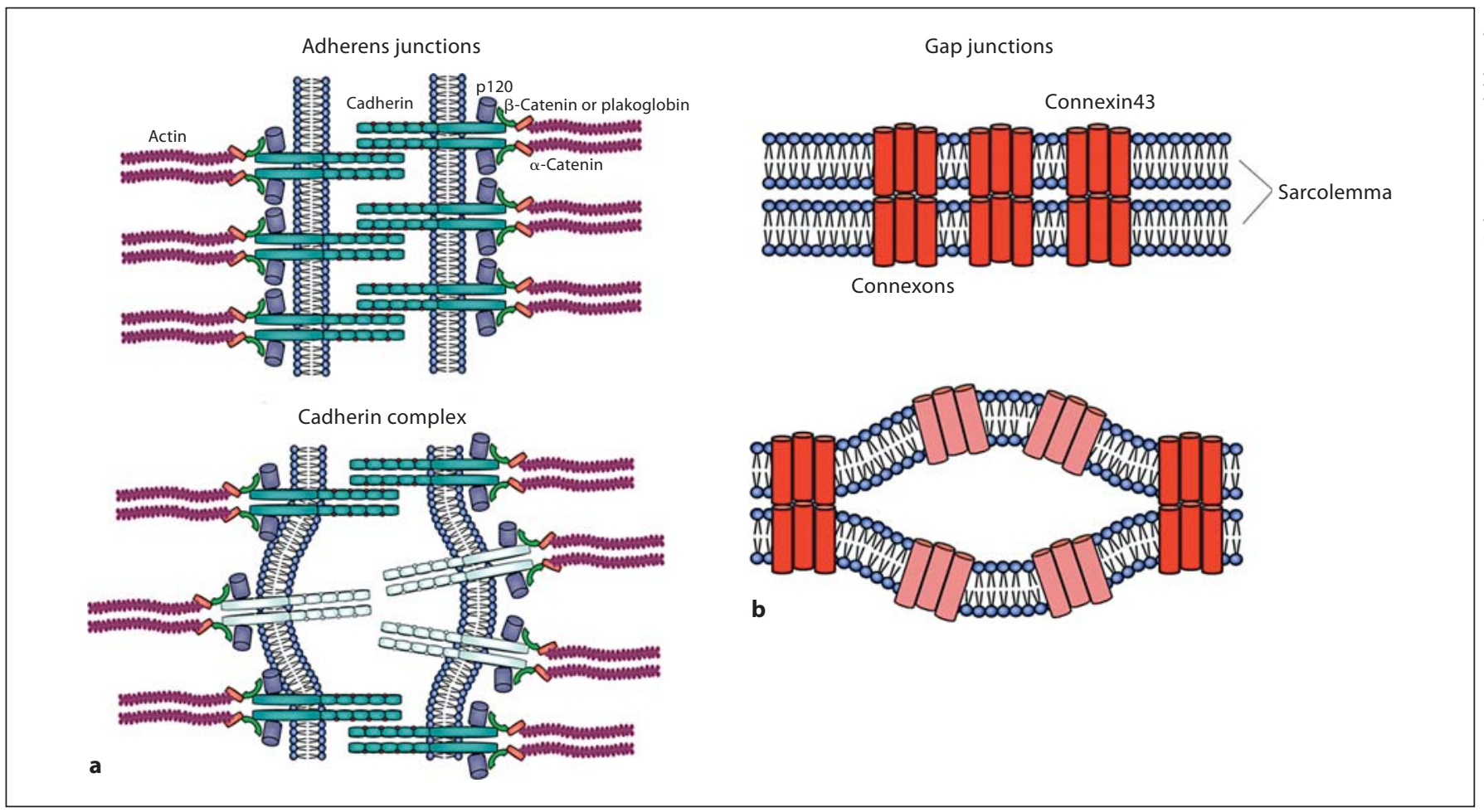

Fig. 4. Schematic diagrams representing adherens and gap junctions in both normal and septic hearts. a In ID of normal myocardium, adherens junction $\mathrm{N}$-cadherin interacts to form a strong zipper structure critical to cell-to-cell adhesion. In septic myocardium the decreased expression of $\mathrm{N}$-cadherin favors a weak zipper structure with adherens junction dehiscence. b In normal myo- cardium gap junction connexin 43 polypeptides (in the schematic drawing only three are represented) form a hemichannel in the membrane of each cell to establish a functional gap junction channel (connexon). In septic myocardium, the decreased expression of connexin43 (missing connexons) favors gap junction dehiscence.

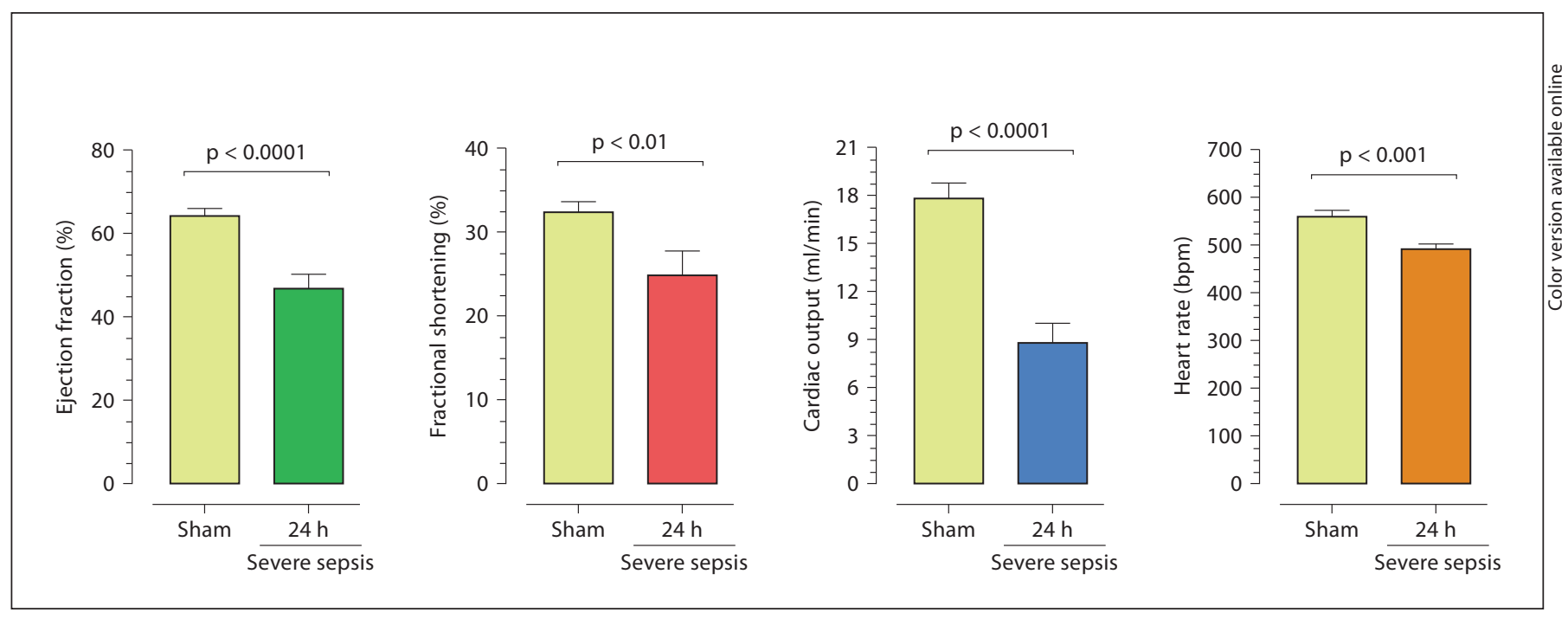

Fig. 5. Cardiac function in mice made septic by CLP and sham-operated controls. Mean ejection fraction, mean fractional shortening, cardiac output and heart rate were significantly reduced in severe sepsis in comparison with sham-operated controls $24 \mathrm{~h}$ after injury. 
shortening, cardiac output and heart rate were significantly reduced compared with sham controls. These observations corroborate previous results demonstrating significantly reduced mean arterial blood pressure in mice submitted to severe sepsis 6 and $12 \mathrm{~h}$ after CLP, which remained markedly decreased $24 \mathrm{~h}$ after injury [85], clearly demonstrating the establishment of septic shock in these animals. The choice of the model, time points and methods used to assess cardiac dysfunction are independent variables that have an important impact on the results of the study. There are some limitations in each model, but the evaluation of cardiac function during the development of experimental sepsis continues to be important to understand the human scenario of this syndrome.

\section{Intracellular Calcium Overload as a Critical Link in the Pathophysiology of Cardiac Dysfunction and Survival in Sepsis}

Calcium generally acts as an important intracellular second messenger. On the other hand, cytoplasmic calcium overload through increased leakage from the sarcoplasmic reticulum and increased cell membrane influx is a well-known cause of cell toxicity and death by activating a number of intracytoplasmic enzymes that cause degradation of cytoplasmic proteins, plasma cell membrane and nuclear DNA [121-123]. There is evidence that calcium is elevated in sepsis. Basal calcium concentration was increased $>2$-fold in aortic smooth muscle cells obtained from rats submitted to CLP [124]. Dantrolene, a drug that abolishes the excitation-contraction coupling in muscle cells inhibiting calcium release from sarcoplasmic reticulum by blocking the skeletal muscle type- 1 and cardiac type- 2 ryanodine receptors (RyR1 and RyR2, respectively) [125] blocked skeletal muscle proteolysis in septic rats through reduced expression of calpain proteases $[126,127]$. Calpain activation is known to cause disruption of the sarcomeres with release of actin and myosin myofilaments that are ubiquinated and subsequently degraded by the proteasome $[128,129]$. Previously, it was demonstrated that dantrolene decreased many of the metabolic abnormalities of sepsis when added to cultured skeletal muscle cells in vitro or when given to rats made septic by CLP and causing $>2$-fold improvement in survival when given concurrently with $E$. coli endotoxin to mice. This suggests that an increase in intracellular calcium plays an important role in the metabolic abnormalities that occur during sepsis [126]. A recent study showed

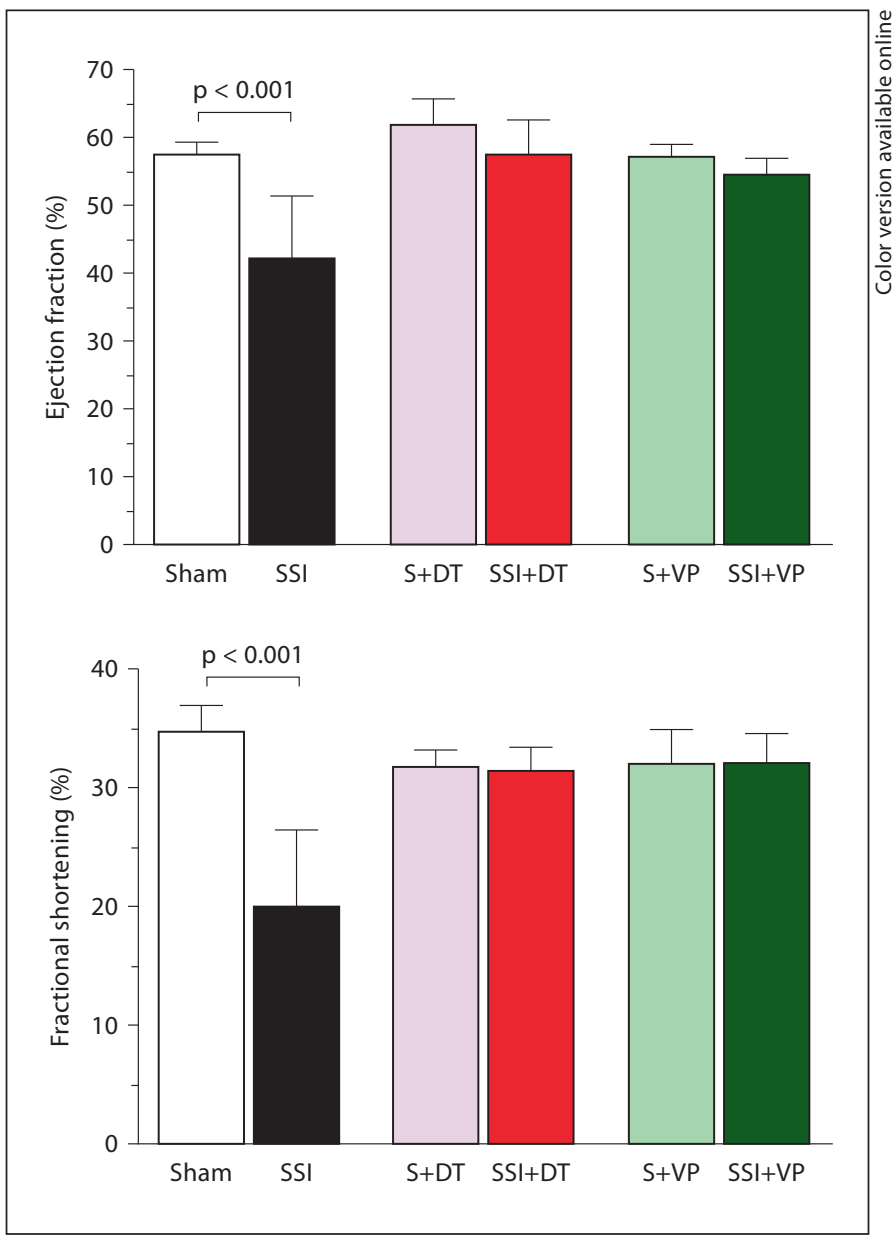

Fig. 6. Cardiac function in mice made septic by CLP compared with sham-operated mice treated with saline (SSI), sham-operated controls treated with dantrolene $(\mathrm{S}+\mathrm{DT})$ compared with mice made septic and treated with dantrolene (SSI+DT) $2 \mathrm{~h}$ after surgery, and sham-operated mice treated with verapamil (S+VP) compared with mice made septic and treated with verapamil (SSI+VP) $2 \mathrm{~h}$ after surgery. Mean ejection fraction decreased $38 \%$ and fractional shortening $42 \% 24 \mathrm{~h}$ after surgery compared with mice submitted to sham operation. These parameters were completely abrogated by dantrolene or verapamil treatment.

that dantrolene prevented dose-dependent calcium leakage from sarcoplasmic reticulum vesicles isolated from control rat hearts; besides, pretreatment with dantrolene resulted in a significant reduction in calcium leakage from sarcoplasmic reticulum vesicles isolated from rat hearts treated with endotoxin LPS obtained from E. coli [130]. The evaluation of myocardial function using a modified Langendorff heart preparation clearly showed that reduction in $\mathrm{LV}$ diastolic pressure, maximum rate of the LV pressure rise $\left(\mathrm{dP} / \mathrm{dt}_{\max }\right)$ and the minimum rate of 


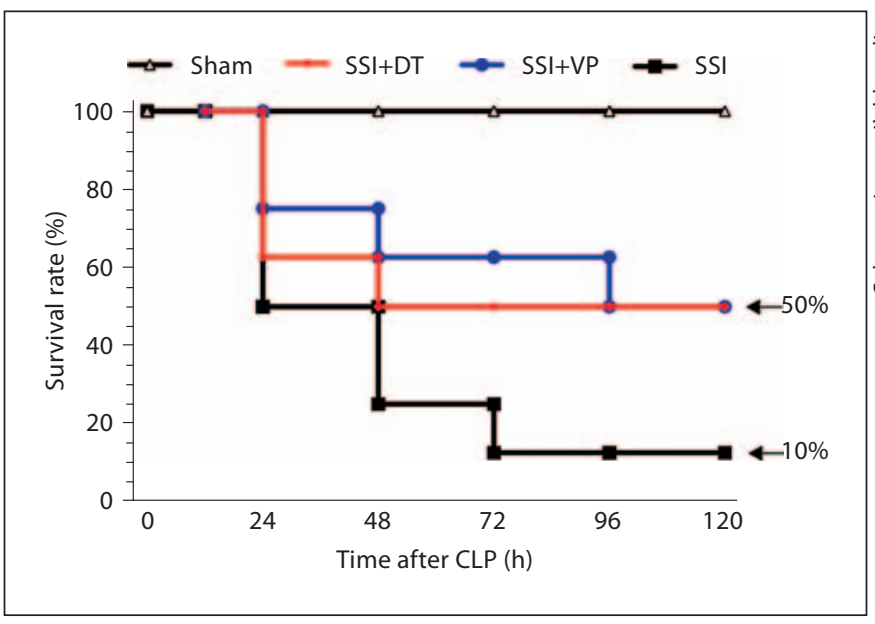

Fig. 7. Percent survival of mice treated $2 \mathrm{~h}$ after septic injury with dantrolene $(10 \mathrm{mg} / \mathrm{kg}$ of body weight; SSI+DT) or verapamil (5 $\mathrm{mg} / \mathrm{kg}$ of body weight; SSI+VP) injected intraperitoneally in comparison with sham-operated controls treated with saline (Sham) and mice made septic treated with saline (SSI) $2 \mathrm{~h}$ after surgery during an experimental period of $120 \mathrm{~h}$. The number of animals per group was 10.

the LV pressure fall $\left(\mathrm{dP} / \mathrm{dt}_{\min }\right)$ were abrogated by dantrolene treatment.

Taking the above-presented observations and findings into account, the hypothesis that calcium blockers, both dantrolene or verapamil, could affect cardiac function in vivo and survival in mice submitted to septic injury was examined [unpubl. results]. Verapamil selectively inhibits calcium influx across the cell membrane of arterial muscle cells, as well as conductible and contractile myocardial cells through the slow channel (calcium ion antagonism) [131]. To this end, severe sepsis was induced in mice through CLP using an 18 -gauge needle. Mice made septic by CLP and treated with saline and sham-operated mice treated with saline served as controls. Septic mice were treated $2 \mathrm{~h}$ after CLP with dantrolene $(10 \mathrm{mg} / \mathrm{kg}$ of body weight) or verapamil (5 mg/kg of body weight) injected intraperitoneally. Controls were given the same volume of saline intraperitoneally. Ejection fraction and fractional shortening were evaluated using a Vevo $2100^{\circledR}$ high-resolution imaging system. Importantly, 38\% reduction in ejection fraction and $43 \%$ reduction in fractional shortening $24 \mathrm{~h}$ after septic injury were completely abrogated by either dantrolene or verapamil treatment (fig. 6). Survival was recorded for 5 days after septic injury or sham operation. There was a 5 -fold improvement in survival rate at the end of the 5-day observation period in mice with sepsis induced by CLP and treated with both calcium inhibitors, i.e. 50\% survival for CLP mice treated with either dantrolene or verapamil versus $10 \%$ survival for CLP mice treated with saline and $100 \%$ survival for sham-operated controls treated with saline only (fig. 7). The partial prevention of the mortality rate in septic mice treated with calcium inhibitors should be ascribed to other causes of death in this pathological process. Importantly, the structure of the myocardium from septic mice given either verapamil or dantrolene appeared normal, similar to that of untreated controls and controls treated with verapamil or dantrolene, beside the preservation of dystrophin disruption (data not shown, original research manuscript in preparation).

\section{Conclusions and Future Directions}

The heart is an important target organ that is structurally damaged by severe sepsis/septic shock. The myocardial changes in long-term human severe sepsis/septic shock can be classified within the group of specific cardiomyopathies and named inflammatory cardiomyopathy. Based on experimental studies, cardiac pathological changes associated with reduced myocardial contractility in severe sepsis/septic shock can be ascribed to the defect in the mechanical connection between the intracellular cytoskeleton of cardiomyocytes and the extracellular matrix, mechanical and electrical/chemical uncoupling of cardiomyocytes, and increased sarcolemmal permeability and structural changes in the contractile apparatus of cardiomyocytes. Importantly, modulation of intracellular calcium and oxidative damage in cardiomyocytes in sepsis may emerge as therapeutic targets that could provide beneficial effects on future cardiovascular outcomes and mortality in this complex disease.

\section{Acknowledgments}

This work was supported by grants from the Fundação de Amparo à Pesquisa do Estado de São Paulo, FAPESP (07/58843-2, 09/17787-8, 09/54010-1 and 10/19216-5), Conselho Nacional de Desenvolvimento Científico e Tecnológico, CNPq (302387/2008$0,470536 / 2008-0$, and 472419/2009-9) and by a Fogarty International Training Grant (D43-TW007129). M.A.R. is Senior Investigator (1A) of CNPq.

\section{Disclosure Statement}

The authors have no conflict of interest to disclose. 


\section{References}

1 Bone RC, Balk RA, Cerra FB, Dellinger RP, Fein AM, Knaus WA, Schein RM, Sibbald WJ: Definitions for sepsis and organ failure and guidelines for the use of innovative therapies in sepsis. The ACCP/SCCM Consensus Conference Committee. American College of Chest Physicians/Society of Critical Care Medicine. Chest 1992;101:1644-1655.

-2 Annane D, Bellissant E, Cavaillon JM: Septic shock. Lancet 2005;365:63-78.

- 3 Parrillo JE, Parker MM, Natanson C, Suffredini AF, Danner RL, Cunnion RE, Ognibene FP: Septic shock in humans. Advances in the understanding of pathogenesis, cardiovascular dysfunction, and therapy. Ann Intern Med 1990;113:227-242.

-4 Vieillard-Baron A, Caille V, Charron C, Belliard G, Page G, Jardin BF: Actual incidence of global left ventricular hypokinesia in adult septic shock. Crit Care Med 2008;36: 1701-1706.

5 Rudiger A, Singer M: Mechanisms of sepsisinduced cardiac dysfunction. Crit Care Med 2007;35:1599-1608.

-6 Doerschug KC, Delsing AS, Schmidt GA, 17 Haynes WG: Impairments in microvascular reactivity are related to organ failure in human sepsis. Am J Physiol Heart Circ Physiol 2007;293:H1065-H1071.

7 Rudiger A: Beta-block the septic heart. Crit Care Med 2010;38:S608-S612.

8 Ackland GL, Yao ST, Rudiger A, Dyson A, Stidwill R, Poputnikov D, Singer M, Gourine AV: Cardioprotection, attenuated systemic inflammation, and survival benefit of beta1adrenoceptor blockade in severe sepsis in rats. Crit Care Med 2010;38:388-394.

$\checkmark$ dos Santos CC, Gattas DJ, Tsoporis JN, Smeding L, Kabir G, Masoom H, Akram A, Plotz F, Slutsky AS, Husain M, Sibbald WJ, Parker TG: Sepsis-induced myocardial depression is associated with transcriptional changes in energy metabolism and contractile related genes: a physiological and gene expression-based approach. Crit Care Med 2010;38:894-902.

10 Lancel S, Hassoun SM, Favory R, Decoster B, Motterlini R, Neviere R: Carbon monoxide rescues mice from lethal sepsis by supporting mitochondrial energetic metabolism and activating mitochondrial biogenesis. J Pharmacol Exp Ther 2009;329:641-648.

$\checkmark 11$ Chopra M, Golden HB, Mullapudi S, Dowhan W, Dostal DE, Sharma AC: Modulation of myocardial mitochondrial mechanisms during severe polymicrobial sepsis in the rat. PLoS One 2011;6:e21285.

-12 Lichtenstern C, Brenner T, Bardenheuer HJ, Weigand MA: Predictors of survival in sepsis: what is the best inflammatory marker to measure? Curr Opin Infect Dis 2012;25:328336.
13 Mink SN, Kasian K, Jacobs H, Cheng ZQ, Light RB: N,N'-diacetylchitobiose, an inhibitor of lysozyme, reverses myocardial depression and lessens norepinephrine requirements in Escherichia coli sepsis in dogs. Shock 2008;29:681-687.

14 Araújo AV, Ferezin CZ, Pereira Ade C, Rodrigues GJ, Grando MD, Bonaventura D, Bendhack LM: Augmented nitric oxide production and up-regulation of endothelial nitric oxide synthase during cecal ligation and perforation. Nitric Oxide 2012;27:59-66.

15 Lancel S, Tissier S, Mordon S, Marechal X, Depontieu F, Scherpereel A, Chopin C, Neviere R: Peroxynitrite decomposition catalysts prevent myocardial dysfunction and inflammation in endotoxemic rats. J Am Coll Cardiol 2004;43:2348-2358.

16 Iwata A, de Claro RA, Morgan-Stevenson VL, Tupper JC, Schwartz BR, Liu L, Zhu X, Jordan KC, Winn RK, Harlan JM: Extracellular administration of BCL2 protein reduces apoptosis and improves survival in a murine model of sepsis. PLoS One 2011;6:e14729.

7 Stengl M, Bartak F, Sykora R, Chvojka J, Benes J, Krouzecky A, Novak I, Sviglerova J, Kuncova J, Matejovic M: Reduced L-type calcium current in ventricular myocytes from pigs with hyperdynamic septic shock. Crit Care Med 2010;38:579-587.

18 Dong LW, Wu LL, Ji Y, Liu MS: Impairment of the ryanodine-sensitive calcium release channels in the cardiac sarcoplasmic reticulum and its underlying mechanism during the hypodynamic phase of sepsis. Shock 2001;16:33-39.

19 Levy MM, Dellinger RP, Townsend SR, Linde-Zwirble WT, Marshall JC, Bion J, Schorr C, Artigas A, Ramsay G, Beale R, Parker MM, Gerlach H, Reinhart K, Silva E, Harvey M, Regan S, Angus DC: The surviving sepsis campaign: results of an international guideline-based performance improvement program targeting severe sepsis. Intensive Care Med 2010;36:222-231.

20 Rossi MA, Celes MRN, Prado CM, Saggioro FP: Myocardial structural changes in longterm human severe sepsis/septic shock may be responsible for cardiac dysfunction. Shock 2007;27:10-18.

21 Muller-Werdan U, Buerke M, Ebelt H, Heinroth KM, Herklotz A, Loppnow H, Ruß M, Schlegel F, Schlitt A, Schmidt HB, Söffker G, Werdan K: Septic cardiomyopathy - a not yet discovered cardiomyopathy? Exp Clin Cardiol 2006;11:226-236.

22 Flierl MA, Rittirsch D, Huber-Lang MS, Sarma JV, Ward PA: Molecular events in the cardiomyopathy of sepsis. Mol Med 2008; 14: 327-336.

23 Hunter JD, Doddi M: Sepsis and the heart. Br J Anaesth 2010;104:3-11.

24 Vieillard-Baron A: Septic cardiomyopathy. Ann Intensive Care 2011;1:6.
25 Adib-Conquy M, Cavaillon JM: Réponse inflammatoire et anti-inflammatoire de l'hôte au cours du sepsis. Pathol Biol (Paris) DOI: 10.1016/j.patbio.2012.03.011, E-pub ahead of print.

26 Bianchi ME: DAMPs, PAMPs and alarmins: all we need to know about danger. J Leukoc Biol 2007;81:1-5.

27 Akira S, Takeda K: Toll-like receptor signaling. Nat Rev Immunol 2004;4:499-511.

28 Park BS, Song DH, Choi B-S, Lee H, Lee J-O: The structural basis of lipopolysaccharide recognition by the TLR4-MD-2 complex. Nature 2009;458:1191-1195.

29 Thomas JA, Haudek SB, Koroglu T, Tsen MF, Bryant DD, White DJ, Kusewitt DF, Horton JW, Giroir BP: IRAK1 deletion disrupts cardiac Toll/IL-1 signaling and protects against contractile dysfunction. Am J Physiol Heart Circ Physiol 2003;285:H597-H606.

30 Soriano FG, Lorigados CB, Pacher P, Szabó C: Effects of a potent peroxynitrite decomposition catalyst in murine models of endotoxemia and sepsis. Shock 2011;35:560-566.

31 Torres-Duenas D, Celes MR, Freitas A, Alves-Filho JC, Spiller F, Dal-Secco D, Dalto VF, Rossi MA, Ferreira SH, Cunha FQ: Peroxynitrite mediates the failure of neutrophil migration in severe polymicrobial sepsis in mice. Br J Pharmacol 2007;152:341-352.

32 Rittirsch D, Flierl MA, Ward PA: Harmful molecular mechanisms in sepsis. Nat Rev Immunol 2008;8:776-787.

33 Bergmann M, Sautner T: Immunomodulatory effects of vasoactive catecholamines. Wien Klin Wochenschr 2002;114:752-761.

34 Osuchowski MF, Welch K, Siddiqui J, Remick DG: Circulating cytokine/inhibitor profiles reshape the understanding of the SIRS/ CARS continuum in sepsis and predict mortality. J Immunol 2006;177:1967-1974.

35 Rittirsch D, Hoesel LM, Ward PA: The disconnect between animal models of sepsis and human sepsis. J Leukoc Biol 2007;81: 137-143.

36 Esmon CT: Why do animal models (sometimes) fail to mimic human sepsis? Crit Care Med 2004;32:S219-S222.

37 Beutler B, Milsark IW, Cerami AC: Passive immunization against cachectin/tumor necrosis factor protects mice from lethal effect of endotoxin. Science 1985;229:869-871.

- 38 Tracey KJ, Fong Y, Hesse DG, Manogue KR, Lee AT, Kuo GC, Lowry SF, Cerami A: Anticachectin/TNF monoclonal antibodies prevent septic shock during lethal bacteraemia. Nature 1987;330:662-664.

39 Fisher CJ Jr, Agosti JM, Opal SM, Lowry SF, Balk RA, Sadoff JC, Abraham E, Schein RM, Benjamin E: Treatment of septic shock with the tumor necrosis factor receptor:Fc fusion protein. The Soluble TNF Receptor Sepsis Study Group. N Engl J Med 1996;334:16971702. 
-40 Abraham E, Laterre PF, Garbino J, Pingleton S, Butler T, Dugernier T, Margolis B, Kudsk K, Zimmerli W, Anderson P, Reynaert M, Lew D, Lesslauer W, Passe S, Cooper P, Burdeska A, Modi M, Leighton A, Salgo M, Van der Auwera P, Lenercept Study Group: Lenercept (p55 tumor necrosis factor receptor fusion protein) in severe sepsis and early septic shock: a randomized, double-blind, placebo-controlled, multicenter phase III trial with 1,342 patients. Crit Care Med 2001; 29:503-510.

41 Fischer E, Marano MA, Van Zee KJ, Rock CS, Hawes AS, Thompson WA, DeForge L, Kenney JS, Remick DG, Bloedow DC: Interleukin-1 receptor blockade improves survival and hemodynamic performance in Escherichia coli septic shock, but fails to alter host responses to sublethal endotoxemia. J Clin Invest 1992;89:1551-1557.

- 42 Fisher CJ Jr, Dhainaut JF, Opal SM, Pribble JP, Balk RA, Slotman GJ, Iberti TJ, Rackow EC, Shapiro MJ, Greenman RL, et al: Recombinant human interleukin 1 receptor antagonist in the treatment of patients with sepsis syndrome. Results from a randomized, double-blind, placebo-controlled trial. Phase III rhIL-1ra Sepsis Syndrome Study Group. JAMA 1994;271:1836-1843.

43 Patel GP, Balk RA: Systemic steroids in severe sepsis and septic shock. Am J Respir Crit Care Med 2012;185:133-139.

-44 Rearte B, Landoni V, Laborde E, Fernández G, Isturiz M: Differential effects of glucocorticoids in the establishment and maintenance of endotoxin tolerance. Clin Exp Immunol 2010;159:208-216.

45 Batzofin BM, Sprung CL, Weiss YG: The use of steroids in the treatment of severe sepsis and septic shock. Best Pract Res Clin Endocrinol Metab 2011;25:735-743.

-46 Sprung CL, Goodman S, Weiss YG: Steroid therapy of septic shock. Crit Care Nurs Clin North Am 2011;23:171-180.

-47 Roger T, Froidevaux C, Le Roy D, Reymond MK, Chanson A-L, Mauri D, Burns K, Riederer BM, Akira S, Calandra T: Protection from lethal Gram-negative bacterial sepsis by targeting Toll-like receptor 4 . Proc Natl Acad Sci USA 2009;106:2348-2352.

48 Matsuyama K: Eisai's sepsis drug eritoran fails to save more lives in final-stage study. http://www.bloomberg.com/news/2011-0125/eisai-s-sepsis-drug-eritoran-fails-tosave-more-lives-in-final-stage-study.html (accessed June 4, 2012).

49 Borgel D, Vieillard-Baron A: La protein Cactivée. Une protéine à l'interface de l'inflammation et de la coagulation. Med Sci (Paris) 2011;27:501-507.

50 Xigris [drotrecogin alfa (activated)]: market withdrawal - failure to show survival benefit. http://www.fda.gov/Safety/MedWatch/ SafetyInformation/SafetyAlertsforHumanMedicalProducts/ucm277143.htm (accessed June 4, 2012).
Leung S, Pokharel R, Gong MN: Statins and outcomes in patients with bloodstream infection. A propensity-matched analysis. Crit Care Med 2012;40:1064-1071.

52 Norbury WB, Jeschke MG, Herdon DN: Metabolism modulators in sepsis: propanolol. Crit Care Med 2007;35:S616-S620.

53 Mori K, Morisaki H, Yajima S, Suzuki T, Ishikawa A, Nakamura N, Innami Y, Takeda J: Beta-1 blocker improves survival of septic rats through preservation of gut barrier function. Intensive Care Med 2011;37:18491856.

54 Suzuki T, Mrisaki H, Serita R, Yamamoto M, Kotake Y, Yshikawa A, Takeda J: Infusion of $\beta$-adrenergic blocker esmolol attenuates myocardial dysfunction in septic hearts. Crit Care Med 2005;33:2294-2301.

55 Schmitz D, Wilsenack K, Lendemanns S, Scheldlowski M, Oberbeck R: Beta-adrenergic blockade during systemic inflammation: impact on cellular immune functions and survival in a murine model of sepsis. Resuscitation 2007;72:286-294.

56 Patterson AJ, Zhu W, Chow A, Agrawal R, Kosek J, Xiao RP, Kobilka B: Protecting the myocardium: a role for beta 2 adrenergic receptor in the heart. Crit Care Med 2004;32: 1041-1048.

57 Zhang F, Wu R, Qiang X, Zhou M, Wang P: Antagonism of $\alpha_{2 \mathrm{~A}}$-adrenoceptor: a novel approach to inhibit inflammatory response in sepsis. J Mol Med 2010;88:289-296.

58 ver Elst KM, Spapen HD, Nguyen DN, Garbar C, Huyghens LP, Gorus FK: Cardiac troponins $\mathrm{I}$ and $\mathrm{T}$ are biological markers of left ventricular dysfunction in septic shock. Clin Chem 2000;46:650-657.

59 Moon VH: The pathology of secondary shock. Am J Pathol 1948;24:235-273.

60 Fernandes Júnior CJ, Iervolino M, Neves RA, Sampaio EL, Knobel E: Interstitial myocarditis in sepsis. Am J Cardiol 1994;74:958.

61 Richardson P, McKenna W, Bristow M, Maisch B, Mautner B, O'Connell J, Olsen E, Thiene G, Goodwin J, Gyarfas I, Martin I, Nordet P: Report of the 1995 World Health Organization/International Society and Federation of Cardiology Task Force on the Definition and Classification of Cardiomyopathies. Circulation 1996;93:841-842.

62 Kapadia S, Lee J, Torre-Amione G, Birdsall HH, Ma TS, Mann DL: Tumor necrosis factor-alpha gene and protein expression in adult feline myocardium after endotoxin administration. J Clin Invest 1995;96:10421052.

63 Meldrum DR: Tumor necrosis factor in the heart. Am J Physiol 1998;274:R577-R595.

64 Zhou YT, Grayburn P, Karim A, Shimabukuro $M$, Higa $M$, Baetens D, Orci L, Unger RH: Lipotoxic heart disease in obese rats: implications for human obesity. Proc Natl Acad Sci USA 2000;97:1784-1789.
65 Remick DG, Newcomb DE, Bolgos GL, Call DR: Comparison of the mortality and inflammatory response of two models of sepsis: lipopolysaccharide vs. cecal ligation and puncture. Shock 2000;13:110-116.

- 66 Wichterman KA, Baue AE, Chaudry IH: Sepsis and septic shock - a review of laboratory models and a proposal. J Surg Res 1980; 29:189-201.

67 Hubbard WJ, Choudhry M, Schwacha MG, Kerby JD, Rue LW 3rd, Bland KI, Chaudry IH: Cecal ligation and puncture. Shock 2005; 24:52-57.

68 Fry DE: Sepsis, systemic inflammatory response and multiple organ dysfunction. The mystery continues. Am Surg 2012;78:1-8.

69 Vincent JL, Ferreira F, Moreno R: Scoring biosystems for assessing organ dysfunction and survival. Crit Care Clin 2000;16:353366.

70 Gustot T: Multiple organ failure in sepsis: prognosis and role of systemic inflammatory response. Curr Opin Crit Care 2011;17:153159.

71 Coalson JJ, Hinshaw LB, Guenter CA, Berrell EL, Greenfield LJ: Pathophysiologic responses of the subhuman primate in experimental septic shock. Lab Invest 1975;32:561-569.

72 Schlag G, Redl H, van Vuuren CJ, Davies J: Hyperdynamic sepsis in baboons: II. Relation of organ damage to severity of sepsis evaluated by a newly developed morphological scoring system. Circ Shock 1992;38:253263.

73 Hersch M, Gnidec AA, Bersten AD, Troster M, Rutledge FS, Sibbald WJ: Histologic and ultrastructural changes in nonpulmonary organs during early hyperdynamic sepsis. Surgery 1990;107:397-410.

74 Gotloib L, Shostak A, Galdi P, Jaichenko J, Fudin R: Loss of microvascular negative charges accompanied by interstitial edema in septic rats' heart. Circ Shock 1992;36:4556.

75 Solomon MA, Correa R, Alexander HR, Koev LA, Cobb JP, Kim DK, Roberts WC, Quezado ZM, Scholz TD, Cunnion RE: Myocardial energy metabolism and morphology in a canine model of sepsis. Am J Physiol 1994;266:H757-H768.

-76 Goddard CM, Allard MF, Hogg JC, Walley KR: Myocardial morphometric changes related to decreased contractility after endotoxin. Am J Physiol 1996;270:H1446-H1452.

77 Piper RD, Li FY, Myers ML, Sibbald WJ: Structure-function relationships in the septic rat heart. Am J Respir Crit Care Med 1997; 156:1473-1482.

78 Zhou M, Wang P, Chaudry IH: Cardiac contractility and structure are not significantly compromised even during the late, hypodynamic stage of sepsis. Shock 1998;9:352-358.

79 Sharma AC, Motew SJ, Farias S, Alden KJ, Bosmann HB, Law WR, Ferguson JL: Sepsis alters myocardial and plasma concentrations of endothelin and nitric oxide in rats. J Mol Cell Cardiol 1997;29:1469-1477. 
80 Ren J, Ren BH, Sharma AC: Sepsis-induced depressed contractile function of isolated ventricular myocytes is due to altered calcium transient properties. Shock 2002;18:285288.

-81 Parrillo JE, Burch C, Shelhamer JH, Parker MM, Natanson C, Schuette W: A circulating myocardial depressant substance in humans with septic shock. Septic shock patients with a reduced ejection fraction have a circulating factor that depresses in vitro myocardial cell performance. J Clin Invest 1985;76:15391553.

-82 Suffredini AF, Fromm RE, Parker MM, Brenner M, Kovacs JA, Wesley RA, Parrillo JE: The cardiovascular response of normal humans to the administration of endotoxin. N Engl J Med 1989;321:280-287.

83 Natanson C, Eichenholz PW, Danner RL, Eichacker PQ, Hoffman WD, Kuo GC, Banks SM, MacVittie TJ, Parrillo JE: Endotoxin and tumor necrosis factor challenges in dogs simulate the cardiovascular profile of human septic shock. J Exp Med 1989;169: 823-832.

84 Yokoyama T, Vaca L, Rossen RD, Durante W, Hazarika P, Mann DL: Cellular basis for the negative inotropic effects of tumor necrosis factor-alpha in the adult mammalian heart. J Clin Invest 1993;92:2303-2312.

$\checkmark 85$ Celes MR, Torres-Dueñas D, Prado CM, Campos EC, Moreira JE, Cunha FQ, Rossi MA: Increased sarcolemmal permeability as an early event in experimental septic cardiomyopathy: a potential role for oxidative damage to lipids and proteins. Shock 2010; 33:322-331.

86 Rossi MA, Santos CS: Sepsis-related microvascular myocardial damage with giant cell inflammation and calcification. Virchows Arch 2003;443:87-92.

-87 Ikeda Y, Martone M, Gu Y, Hoshijima M, Thor A, Oh SS, Peterson KL, Ross J: Altered membrane proteins and permeability correlate with cardiac dysfunction in cardiomyopathic hamsters. Am J Physiol Heart Circ Physiol 2000;278:H1362-H1370.

88 Chagnon F, Bentourkia M, Lecomte R, Lessard M, Lesur O: Endotoxin-induced heart dysfunction in rats: assessment of myocardial perfusion and permeability and the role of fluid resuscitation. Crit Care Med 2006; 34:127-133.

89 Rodríguez M, Cai WJ, Kostin S, Lucchesi BR, Schaper J: Ischemia depletes dystrophin and inhibits protein synthesis in the canine heart: mechanisms of myocardial ischemic injury. J Mol Cell Cardiol 2005;38:723-733.

90 Campos EC, Romano MM, Prado CM, Rossi MA: Isoproterenol induces primary loss of dystrophin in rat hearts: correlation with myocardial injury. Int J Exp Pathol 2008;89: 367-381.
91 Borg TK, Terracio L: Interaction of the extracellular matrix with cardiac myocytes during development and disease; in Robinson TF, Kinne RKH (eds): Cardiac Myocyte-Connective Tissue Interactions in Health and Disease. Basel, Karger, 1990, pp 113-130.

92 Robinson TF, Cohen-Gould L, Factor SM: Skeletal framework of mammalian heart muscle. Arrangement of inter- and pericellular connective tissue structures. Lab Invest 1983;49:482-498.

93 Klietsch R, Ervasti JM, Arnold W, Campbell KP, Jorgensen AO: Dystrophin-glycoprotein complex and laminin colocalize to the sarcolemma and transverse tubules of cardiac muscle. Circ Res 1993;72:349-360.

-94 Hein S, Kostin S, Heling A, Maeno Y, Schaper $\mathrm{J}$ : The role of the cytoskeleton in heart failure. Cardiovasc Res 2000;45:273-278.

$\checkmark 95$ Kostin S, Hein S, Arnon E, Scholz D, Schaper J: The cytoskeleton and related proteins in the human failing heart. Heart Fail Rev 2000;5:271-280.

-96 Lapidos KA, Kakkar R, McNally EM: The dystrophin glycoprotein complex: signaling strength and integrity for the sarcolemma. Circ Res 2004;94:1023-1031.

97 Oliviéro P, Chassagne C, Salichon N, Corbier A, Hamon G, Marotte F, Charlemagne D, Rappaport L, Samuel JL: Expression of laminin alpha2 chain during normal and pathological growth of myocardium in rat and human. Cardiovasc Res 2000;46:346355.

98 Heydemann A, McNally EM: Consequences of disrupting the dystrophin-sarcoglycan complex in cardiac and skeletal myopathy. Trends Cardiovasc Med 2007;17:55-59.

$\$ 99$ Celes MR, Torres-Dueñas D, Malvestio LM, Blefari V, Campos EC, Ramos SG, Prado CM, Cunha FQ, Rossi MA: Disruption of sarcolemmal dystrophin and beta-dystroglycan may be a potential mechanism for myocardial dysfunction in severe sepsis. Lab Invest 2010;90:531-542.

100 Stevenson S, Rothery S, Cullen MJ, Severs NJ: Spatial relationship of the C-terminal domains of dystrophin and beta-dystroglycan in cardiac muscle support a direct molecular interaction at the plasma membrane interface. Circ Res 1998;82:82-93.

101 Jung C, Martins AS, Niggli E, Shirokova N: Dystrophic cardiomyopathy: amplification of cellular damage by $\mathrm{Ca}^{2+}$ signalling and reactive oxygen species-generating pathways. Cardiovasc Res 2008;77:766-773.

102 Khairallah M, Khairallah R, Young ME, Dyck JR, Petrof BJ, Des Rosiers C: Metabolic and signaling alterations in dystrophindeficient hearts precede overt cardiomyopathy. J Mol Cell Cardiol 2007;43:119-129.

103 Straub V, Bittner RE, Léger JJ, Voit T: Direct visualization of the dystrophin network on skeletal muscle fiber membrane. J Cell Biol 1992;119:1183-1191.
104 Rybakova IN, Patel JR, Ervasti JM: The dystrophin complex forms a mechanically strong link between the sarcolemma and costameric actin. J Cell Biol 2000;150: 1209-1214.

105 Ervasti JM, Ohlendieck K, Kahl SD, Gaver MG, Campbell KP: Deficiency of a glycoprotein component of the dystrophin complex in dystrophic muscle. Nature 1990 345:315-319.

106 Severs NJ: The cardiac muscle cell. Bioessays 2000;22:188-199.

107 Gutstein DE, Liu FY, Meyers MB, Choo A, Fishman GI: The organization of adherens junctions and desmosomes at the cardiac intercalated disc is independent of gap junctions. J Cell Sci 2003;116:875-885.

108 Jamora C, Fuchs E: Intercellular adhesion, signaling and the cytoskeleton. Nat Cell Biol 2002;4:E101-E108.

109 Severs NJ, Bruce AF, Dupont E, Rothery S: Remodelling of gap junctions and connexin expression in diseased myocardium. Cardiovasc Res 2008;80:9-19.

110 Evans WH, Martin PE: Gap junctions: Structure and function (review). Mol Membr Biol 2002;19:121-136.

- 111 Celes MR, Torres-Dueñas D, Alves-Filho JC, Duarte DB, Cunha FQ, Rossi MA: Reduction of gap and adherens junction proteins and intercalated disc structural remodeling in the hearts of mice submitted to severe cecal ligation and puncture sepsis. Crit Care Med 2007;35:2176-2185.

- 112 Kostetskii I, Li J, Xiong Y, Zhou R, Ferrari VA, Patel VV, Molkentin JD, Radice GL: Induced deletion of the N-cadherin gene in the heart leads to dissolution of the intercalated disc structure. Circ Res 2005;96:346354.

113 Li J, Patel VV, Kostetskii I, Xiong Y, Chu AF, Jacobson JT, Yu C, Morley GE, Molkentin JD, Radice GL: Cardiac-specific loss of Ncadherin leads to alteration in connexins with conduction slowing and arrhythmogenesis. Circ Res 2005;97:474-481.

-114 Hertig CM, Eppenberger-Eberhardt M Koch S, Eppenberger HM: N-cadherin in adult rat cardiomyocytes in culture. I. Functional role of N-cadherin and impairment of cell-cell contact by a truncated $\mathrm{N}$ cadherin mutant. J Cell Sci 1996;109:1-10.

115 Zuppinger C, Schaub MC, Eppenberger HM: Dynamics of early contact formation in cultured adult rat cardiomyocytes studied by $\mathrm{N}$-cadherin fused to green fluorescent protein. J Mol Cell Cardiol 2000;32: 539-555.

116 Gutstein DE, Morley GE, Tamaddon H, Vaidya D, Schneider MD, Chen J, Chien KR, Stuhlmann H, Fishman GI: Conduction slowing and sudden arrhythmic death in mice with cardiac-restricted inactivation of connexin43. Circ Res 2001;88:333-339. 
117 van Rijen HV, Eckardt D, Degen J, Theis M, Ott T, Willecke K, Jongsma HJ, Opthof T, de Bakker JM: Slow conduction and enhanced anisotropy increase the propensity for ventricular tachyarrhythmias in adult mice with induced deletion of connexin 43 . Circulation 2004;109:1048-1055.

118 Parker MM, Parrillo JE: Septic shock. Hemodynamics and pathogenesis. JAMA 1983;250:3324-3327.

119 Parker MM, Suffredini AF, Natanson C, Ognibene FP, Shelhamer JH, Parrillo JE: Responses of left ventricular function in survivors and nonsurvivors of septic shock. J Crit Care 1989;4:19-25.

120 Krishnagopalan S, Kumar A, Parrillo JE: Myocardial dysfunction in the patient with sepsis. Curr Opin Crit Care 2002;8:376388.

121 Rasmussen H: The calcium messenger system (1). N Engl J Med 1986;314:1094-1101.

-122 Nicotera P, Bellomo G, Orrenius S: Calcium-mediated mechanisms in chemically induced cell death. Annu Rev Pharmacol Toxicol 1992;32:449-470.
23 Schanne FA, Kane AB, Young EE, Farber JL: Calcium dependence of toxic cell death: a final common pathway. Science 1979;206: 700-702.

124 Song SK, Karl IE, Ackerman JJ, Hotchkiss RS: Increased intracellular Ca2+: a critical link in the pathophysiology of sepsis? Proc Natl Acad Sci USA 1993;90:3933-3937.

125 Kobayashi S, Yano M, Suetomi T, Ono M, Tateishi H, Mochizuki M, Xu X, Uchinoumi H, Okuda S, Yamamoto T, Koseki N, Kyushiki H, Ikemoto N, Matsuzaki M: Dantrolene, a therapeutic agent for malignant hyperthermia, markedly improves the function of failing cardiomyocytes by stabilizing interdomain interactions within the ryanodine receptor. J Am Coll Cardiol 2009;53:1993-2005.

126 Hotchkiss RS, Karl IE: Dantrolene ameliorates the metabolic hallmarks of sepsis in rats and improves survival in a mouse model of endotoxemia. Proc Natl Acad Sci USA 1994;91:3039-3043.

127 Fischer DR, Sun X, Williams AB, Gang G, Pritts TA, James JH, Molloy M, Fischer JE, Paul RJ, Hasselgren PO: Dantrolene reduces TNF $\alpha$ and corticosterone levels and muscle calcium, calpain gene expression, and protein metabolism in septic rats. Shock 2001;15:200-207.
28 Wray CJ, Sun X, Gang GI, Hasselgren PO: Dantrolene downregulates the gene expression and activity of the ubiquitin-proteasome proteolytic pathway in septic skeletal muscle. J Surg Res 2002;104:82-87.

129 Smith IJ, Lecker SH, Hasselgren PO: Calpain activity and muscle wasting in sepsis. Am J Physiol Endocrinol Metab 2008; 295:E768-E771.

130 Hassoun SM, Marechal X, Montaigne D, Bouazza Y, Decoster B, Lancel S, Neviere $\mathrm{R}$ : Prevention of endotoxin-induced sarcoplasmic reticulum calcium leak improves mitochondrial and myocardial dysfunction. Crit Care Med 2008;36: 2590-2596.

131 Lee KS, Tsien RW: Mechanism of calcium channel blockade by verapamil, D600, diltiazem and nitrendipine in single dialysed heart cells. Nature 1983;302:790-794. 